\title{
UC ANR research and education influences landscape water conservation and public policy
}

\author{
For more than 30 years, UC has tackled the obstacles that inhibit widespread landscape water \\ conservation, with new science, trainings and contributions to state policy.
}

by Janet S. Hartin, Lorence R. Oki, David W. Fujino, Karrie Reid, Charles A. Ingels, Darren L. Haver and William N. Baker

$\mathrm{F}$ or nearly three decades, California has mandated practices to improve landscape water use efficiency and conservation. The goal of state policies has been to ensure a steady and reliable water source while maintaining healthy sustainable landscapes. Strategies have included the adoption of landscape irrigation standards, water budgets and tiered water rates favoring conservation, and also increased education to the landscape industry and the public.

UC has been influential in developing and providing credible science-backed information to inform legislative actions. It has also reduced the obstacles that were inhibiting widespread landscape water conservation: a lack of credible information regarding landscape water requirements, inadequate training across a large segment of the landscape industry, lagging irrigation system technology, and an inadequate supply of locally available drought-resistant landscape plants.

\section{Abstract}

UC has been heavily involved in research and extension efforts impacting landscape water conservation legislation for over 30 years. In 1981, UC implemented the California Irrigation Management Information System, a network of weather stations that provides data for local estimates of plant water needs. Those estimates led to UC being able to advise the California Legislature on policies for maximum applied water allowances for residential and large landscaping projects. The allowances have been reduced significantly with UC guidance, and UC has helped landscapers to meet the increasingly restrictive requirements. Best practices that reduce water losses have been developed in collaboration with equipment manufacturers and landscaping specialists, and explained to end users. In addition, UC has developed the WUCOLS database, which classifies over 3,500 plants by their water needs. UC's involvement in landscape water conservation continues on many fronts, developing science and contributing to policy.

\section{Online: https://doi.org/10.3733/ca.2018a0041}

UCCE Advisor Chuck Ingels speaks to the press in Sacramento about water conservation. UC has developed a database that categorizes 3,500 plants by their water needs.
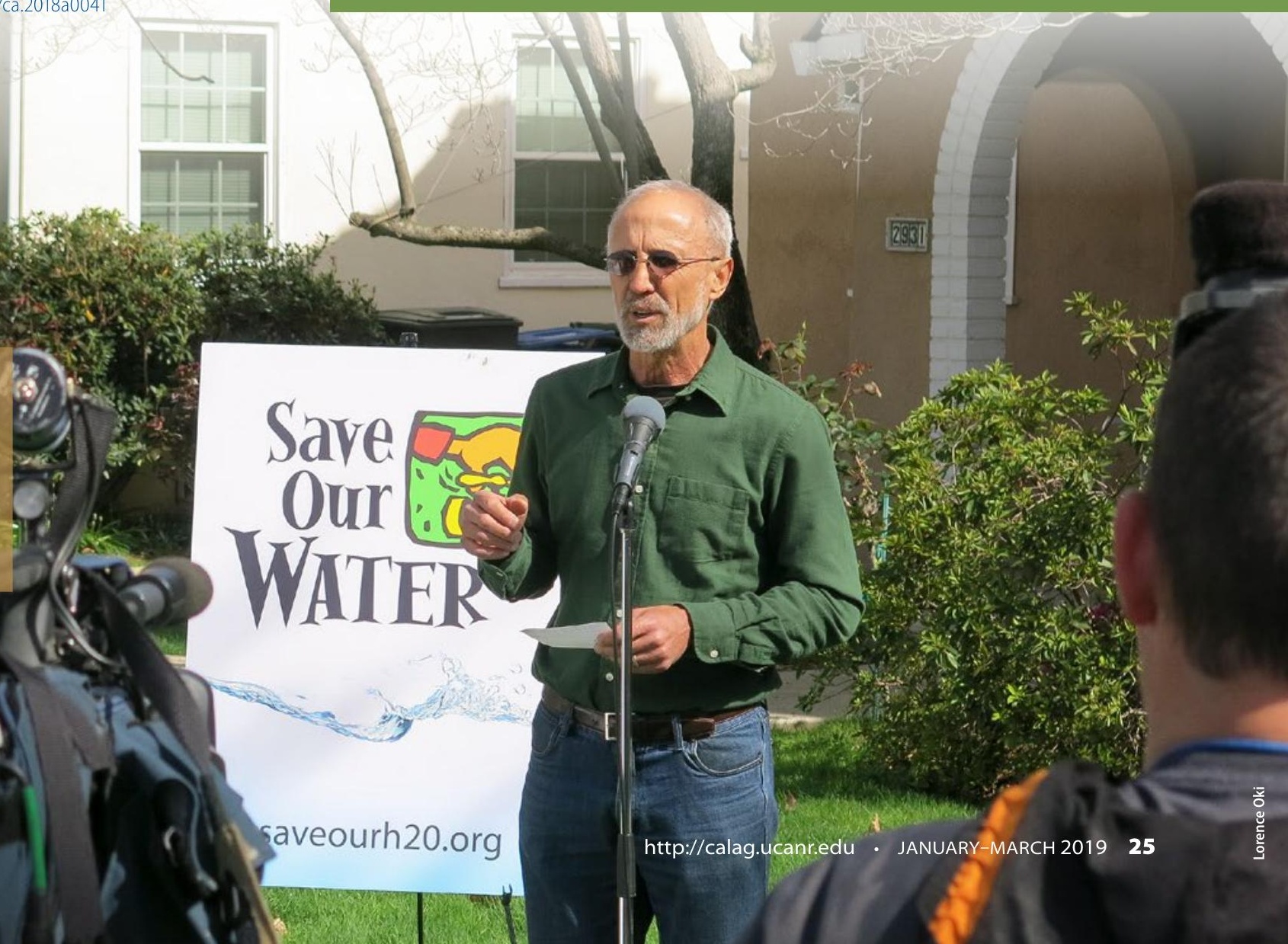
Between $40 \%$ and $60 \%$ of the potable water supply used in urban areas is applied to large-scale and residential landscapes (Kjelgren et al. 2000; St. Hilaire et al. 2008), and up to $60 \%$ of water applied by overhead sprinklers is lost due to runoff from soil surfaces, deep percolation below root zones and soil evaporation (Hartin and McArthur 2007; Hartin et al. 2017). With California's population expected to increase from 39 million to 60 million by 2050 (Dieter and Maupin 2017), water conservation in small residential landscapes and large landscaped areas, such as commercial sites, parks and school grounds, will remain critical,

\section{Glossary}

Evapotranspiration (ET): The water evaporated from soil around plants and the water taken up by plants through transpiration, expressed in inches per unit time.

Reference evapotranspiration (ET $\mathbf{T}_{\mathbf{0}}$ ): An estimate of water used by a healthy, well-watered, full-covered surface of cool-season turfgrass maintained at 4 to 7 inches tall at a given location; determined by temperature, solar radiation, wind speed and relative humidity (real-time ETo for approximately 140 weather stations throughout California can be found at cimis.water.ca.gov).

Plant factor (PF): Reflects the specific water need of a given plant species (usually a noncrop plant) expressed as a fraction of $E T_{0}\left(E T_{C}=E T_{0} \times P F\right)$.

Crop coefficient $\left(\mathbf{K}_{\mathbf{c}}\right)$ : Reflects the specific water needs of a given crop plant grown in a monoculture $\left(E T_{C}=E T_{0} \times K_{c}\right)$; in landscape settings, generally used solely for turfgrass and groundcover species.

Irrigation efficiency (IE): The portion of the total applied irrigation water taken up by the plant; low IE indicates a significant fraction of applied water is lost through runoff and evaporation from surrounding soil.

Evapotranspiration adjustment factor (ETAF): Ratio of PF or $\mathrm{K}_{c}$ to irrigation efficiency (ETAF = PF or $\mathrm{K}_{\mathrm{c}} / \mathrm{IE}$ ); in California, landscape water demand standards are set according to a maximum allowable ETAF value, which recognizes that overall water efficiency depends on both plant species (reflected in the plant factor) and an efficient, well-maintained irrigation system.

Maximum applied water allowance (MAWA): The maximum amount of water needed to irrigate a specified landscaped area, expressed in gallons per year; based on the reference evapotranspiration (ETo), evapotranspiration adjustment factor (ETAF) and the size of the landscaped area.

TABLE 1. Plant factors (PF)/crop coefficients $\left(K_{c}\right)$ for established landscape plants in California

\begin{tabular}{|l|l|}
\hline Plant type & $\begin{array}{c}\text { Plant factor (PF)*/ } \\
\text { Crop coefficient (K }) \dagger\end{array}$ \\
\hline Landscape plants with high water use & $0.7-0.9^{*}$ \\
\hline $\begin{array}{l}\text { Landscape plants with medium/moderate } \\
\text { water use }\end{array}$ & $0.4-0.6^{*}$ \\
\hline Landscape plants with low water use & $0.1-0.3^{*}$ \\
\hline $\begin{array}{l}\text { Landscape plants with very low water use } \\
\text { Warm-season turfgrass (Bermudagrass, zoysiagrass, } \\
\text { St. Augustinegrass, buffalograss) } \\
\text { Cool-season turfgrass (tall fescue, Kentucky } \\
\text { bluegrass, ryegrass, bentgrass) }\end{array}$ & $0.1^{*}$ \\
\hline
\end{tabular}

and temporary water restrictions imposed during drought are likely to become permanent in many parts of the state.

Water conservation will need to offset the growth in demand. Nearly one-half of the state's population growth since 2005 has occurred in inland Southern California and the Central Valley due to the lower housing costs in these areas (Hanak and Davis 2006). These inland properties require higher amounts of supplemental water than coastal areas due to warmer climates and larger landscaped areas.

\section{The science of landscape water use}

Determining how much water is required by heterogeneous landscapes containing multiple species of plants is more complicated than determining the water needs of a field of a single crop species. It would be challenging and time consuming to assess the water requirements of the thousands of native and nonnative landscape plants that are suited to California's Mediterranean climate. Moreover, urban landscape plantings vary in density (plants per unit area), which can significantly alter the water needs of a landscape. In addition, the urban environment includes a variety of microclimates; shade by tall plant species and buildings and other factors commonly create microclimates that influence water needs (Nouri et al. 2016; St. Hilaire et al. 2008).

UC has been heavily involved in developing strategies that directly respond to these challenges (Hartin et al. 2018). In 1981, the pioneering California Irrigation Management Information System (CIMIS) weather station network was set up, a collaboration between UC and the California Department of Water Resources (CDWR). Today, there are more than 145 automated CIMIS weather stations in distinct climate zones throughout the state.

Most CIMIS stations record data on a collection of variables needed to determine the reference evapotranspiration $\left(\mathrm{ET}_{\mathrm{o}}\right)$ at a given location, providing the basis for local estimates of plant water needs. Data from the CIMIS network also allowed UC to establish crop coefficient $\left(\mathrm{K}_{\mathrm{c}}\right)$ values for turfgrass (Gibeault et al. 1985 ) and plant factor (PF) values for other landscape species (Hartin et al. 2018). $\mathrm{K}_{\mathrm{c}}$ and PF values adjust reference evapotranspiration for a particular landscape species or mix of species (table 1). (See the glossary for definitions of terms.)

A major finding by UC was that the health of most landscape plants generally is not impaired when plants are irrigated somewhat below their evapotranspiration rate, a practice known as deficit irrigation. This knowledge led to the identification, through replicated field trials, of minimum irrigation requirements for several species of landscape trees, shrubs and groundcovers (Harivandi et al. 2009; Hartin et al. 1993; Oki et al. 2016; Pittenger et al. 2001; Pittenger et al. 2009; Reid and Oki 2008, 2013, 2016). 
UC also has been a major developer and extender of credible information on landscape water use through peer-reviewed publications; presentations to industry decision-makers at workshops, seminars, conferences and field days; and the UC Agriculture and Natural Resources (UC ANR) Master Gardener program. This work has been instrumental in implementing the multiple pieces of landscape water use legislation that California has adopted since 1990.

\section{AB 325: Water Conservation in Landscaping Act (1990)}

The Water Conservation in Landscaping Act of 1990 required CDWR to convene an advisory task force to develop a Model Water Efficient Landscape Ordinance (MWELO), which was adopted by the legislature in 1993 (State of California 2010). Central to MWELO was the establishment of a maximum applied water allowance (MAWA) based on the size of the landscape and the climate zone.

The formula for calculating MAWA includes an evapotranspiration adjustment factor (ETAF) based on plant factor and irrigation efficiency. MWELO set a maximum ETAF of 0.8 for new commercial and residential landscapes irrigated with potable water. To not exceed this standard, landscapes generally needed to include plants with low and very low water requirements and well-designed, functional irrigation systems. Each jurisdiction is required to either adopt MWELO or update its own landscape ordinance to be equally effective in conserving water.

\section{UC's role}

MWELO required that local jurisdictions categorize plants based on water needs and climate zones. The CDWR and U.S. Bureau of Reclamation provided funding for UC, under the direction of Emeritus UC Cooperative Extension (UCCE) Advisor Laurence Costello, to oversee the development of such a database. WUCOLS (Water Use Classification of Landscape Species) categorized thousands of species of landscape plants in six climate zones (North Central Valley, Central Valley, South Coastal, South Inland Valley, High and Intermediate Desert, and Low Desert) by their water use: very low, low, medium, and high. The work relied on the consensus of 36 experts from the public and private sectors, including UC.

Since the inception of WUCOLS in 1992, additional species have been added, with major updates in 1994, 1999 and 2014. Currently, WUCOLS includes more than 3,500 plants (Costello and Jones 2014); and several teams of UC scientists are engaged in assessing the minimum water requirements of additional landscape species, to add them to the database. The WUCOLS database greatly supplements information from the
Well-designed landscapes with efficient irrigation systems and droughtresistant plants help ensure water budget compliance.




relatively small number of replicated field studies (which are likely more valid but much lengthier and more resource intensive) that have directly measured the water use of individual landscape plant species.

\section{AB 2717: California Urban Water Conservation Council, stakeholders (2004)}

AB 2717 further refined landscape water conservation legislation, using recommendations by a task force appointed by the California Urban Water Conservation Council (now called the California Water Efficiency Partnership, CalWEP). Task force members represented both public and private stakeholders. The final report - Water Smart Landscapes for California: AB 2717 Landscape Task Force Findings, Recommendations, and Actions - was submitted to the Governor and Legislature in December 2005 (CUWCC 2005). It included 43 recommendations regarding best practices to improve water use efficiency in new and existing urban landscapes. The top 12 recommendations are listed in table 2 .

\section{UC's role}

UCCE's Laurence Costello and Janet Hartin were appointed to the task force along with 28 members representing CDWR, the California State Water Resources Control Board (SWRCB), the California Bay Delta Authority, the U.S. Bureau of Reclamation and also the landscape, equipment manufacturing, building and construction industries, and urban water suppliers, environmental advocacy and environmental justice groups, the League of California Cities and the California State Association of Counties. UCCE's Lorence Oki, Ali Harivandi (emeritus) and Robert Green (currently at California Polytechnic State University, Pomona) served as UC representatives on task force working groups.

TABLE 2. Top 12 of the 43 recommendations made by the $A B 2717$ task force

\begin{tabular}{|l|l|}
\hline 1. & Adopt water-conserving rate structures as defined by the task force \\
\hline 2. & Reduce the ETAF (landscape water budget) in MWELO and review it every 10 years for \\
possible further reduction
\end{tabular}

A key topic of debate among task force members was whether new landscapes should be required to contain a minimum percentage of drought-resistant plants or if adequate water savings could be realized based on a water budget through a variety of other means. The task force ultimately recommended the more flexible latter approach, leaving plant selection to the property owner.

UC task force members and other groups represented on the task force (such as the California Landscape Contractors Association) supported exemptions from MWELO's mandated water budgets for "special landscape areas." These areas included recreational turf (sports fields and parks) and areas irrigated with recycled water. While synthetic turf is a viable water-saving alternative to natural turf in some instances, it can result in undesirable impacts such as high surface temperatures in inland and desert areas (Williams and Pulley 2003) and a greater number of player injuries (McNitt et al. 2008).

Several UC academics and other authors, led by Professor Emeritus Ken Tanji, compiled an extensive review of irrigating landscapes with recycled water in Southern California (Tanji et al. 2007) to reduce reliance on potable water. While irrigating landscape plants with recycled water is viable in many situations, salts tend to occur in higher concentrations in recycled water. Leaching these salts below the root zone to prevent plant damage can increase the net water requirement above 1.0 ETAF, the current MWELO allocation for special landscape areas. UC ANR specialists (Haghverdi and Wu 2018) recently published a white paper in support of increasing the ETAF above 1.0 for areas irrigated with recycled water, to provide enough water for leaching.

\section{$A B$ 1881: Water Conservation in Landscaping Act (2006)}

AB 1881 required CDWR to update MWELO by enacting many of the recommendations from the $\mathrm{AB}$ 2717 task force. These included decreasing ETAF from 0.8 to 0.7 for new non-single-family developments with landscaped areas larger than 2,500 square feet "pending a study conducted by UC supporting this recommendation." Local jurisdictions were required by Jan. 1, 2010, to adopt the updated MWELO or adopt a local ordinance that was at least as effective in conserving water.

\section{UC's role}

Many of the recommendations developed by UC and other members of the task force were enacted in this bill. These included requiring selection of plants adapted to specific sites while not prohibiting or requiring specific plant species, encouraging the capture and retention of stormwater on-site and the use of recycled water, conducting on-site soil assessment and management to prevent erosion and water runoff, applying 
mulch around shrub and tree plantings, endorsing education of water users on water conservation practices, and encouraging economic incentives to promote water conservation.

As importantly, the legislation encouraged landscape maintenance practices that lead to long-term water conservation, such as routine irrigation system audits, maintaining functional equipment, and minimizing landscape irrigation overspray and runoff. To that end, classes approved by the U.S. Environmental Protection Agency (US EPA) WaterSense program that increase water use efficiency and decrease water loss are regularly offered by the California Landscape Contractors Association, the Qualified Water Efficient Landscaper program, and Rain Bird. The classes promote the incorporation of water-efficient irrigation practices pertaining to irrigation system design, installation and maintenance, and they often include hands-on demonstrations of irrigation system audits. Attendees gain knowledge of best practices that promote healthy water-conserving landscapes and earn certificates of completion, which may provide career advancement opportunities.

The bill also required the California Energy Commission to regulate performance standards and labeling requirements for irrigation equipment to conserve energy and water. Examples of heightened performance standards include requiring matched precipitation rate sprinkler heads and other emission devices; separate valves for tree and turf irrigation whenever possible; and the use of original components (or their equivalents) for sprinkler repair.

\section{Two UC studies funded by CDWR}

Between 2003 and 2015, UC received CDWR funding to conduct two studies to further refine provisions within AB 1881. Both studies involved identifying the relative importance and impact of specific best practices - such as conducting sprinkler equipment performance audits and scheduling irrigations based on climate and plant water needs - that maintain the health, performance and aesthetics of large-scale public and private landscapes under reduced water budgets.

\section{More than $70 \%$ of applied water was lost}

The first study (Hartin and McArthur 2007) examined major causes of water loss on 30 park, school district, commercial and golf course sites in Los Angeles, Riverside and San Bernardino counties. Results identified that over $70 \%$ of applied water was lost, due mainly to leaks, sunken heads, improper head tilt, unmatched sprinklers, broken or worn parts, overspray, deflected spray, and improper pressure and line or head placement. The results validated the importance of including best practices targeting irrigation system installation and maintenance in water conservation legislation recommended by the $\mathrm{AB} 2717$ task force. Results of this UC study were also included in a white paper published by CDWR that stressed the importance of best practices in landscape water conservation.

\section{Determining validity of reducing ETAF to 0.7}

The second CDWR-funded study (led by California Center for Urban Horticulture Director David Fujino and UC ANR's Loren Oki and Janet Hartin) was conducted by us, the authors of this article, in response to the legislative mandate for a UC study to determine the impact of reducing ETAF from 0.8 to 0.7 (a 19\% reduction) on plant health, function and appearance. We monitored these factors and the water use of 30 large landscapes (parks, school grounds, private grounds, business parks and golf courses) with a wide variety of species, microclimates, densities, irrigation schedules and technologies in six climatic zones throughout the state. Of the 30 sites, 21 performed adequately at 0.7 ETAF after implementing best practices that improved irrigation system functioning and decreased water loss (Hartin et al. 2017; Reid et al. 2017), legitimizing the proposed ETAF reduction, which took effect Jan. 1, 2010.

\section{Some of the greatest water savings in our study came from improving distribution uniformity and irrigation efficiency.}

Some of the greatest water savings in our study came from improving distribution uniformity and irrigation efficiency. With those improvements, warmseason turfgrasses met the 0.7 ETAF standard without impairment to plant health, plant function or aesthetics. Warm-season turf species are more drought resistant than cool-season species; cool-season species did not meet the 0.7 ETAF standard since they are less drought resistant than warm-season species.

All 24 shrub sites used considerably less water than the turf sites, although 10 of them increased water use the second year (ETAFs of 0.58 and 0.61 , respectively) due to malfunctioning valves and management turnover that led to a lack of continuity in site maintenance. Results suggest that drip-irrigated and mulched areas of plants with a mix of medium, low and very low water needs and small areas of warm-season turf can perform adequately at 0.7 ETAF.

The results of this study underscored the importance of the MWELO exemptions for special landscape areas. In the absence of an exemption for recreational turf, the options to meet the 0.7 ETAF include reducing the acreage of cool-season turf species, replacing coolseason species with warm-season species or irrigating the landscape with nonpotable water.

Another goal of the CDWR-funded ETAF study was to expand the number of plants listed in WUCOLS. In addition to CDWR, many organizations supported this effort, including the Association of Professional Landscape Designers, American 
Society of Irrigation Consultants, American Society of Landscape Architects, California Association of Nurseries and Garden Centers, and the California Landscape Contractors Association. The most recent WUCOLS update, WUCOLS IV (Costello and Jones 2014), includes the water use classification of an additional 1,500 ornamental plants, bringing the total to 3,546 entries.

Analytical user data indicates high usage of WUCOLS. During 2014 there were 7,300 users and over 130,000 page views, which increased to over 25,000 users and 538,000 page views during 2016. There was a slight decrease in hits in 2017, perhaps due to an easing of the drought-related water restrictions that had been imposed by Governor Brown in 2015.

Outreach was a major component of the ETAF study. Between 2013 and 2017, our team reached over 7,000 landscape industry professionals through presentations at workshops, symposia, field days and conferences sponsored by UC and industry organizations such as the California Landscape Contractors Association, Irrigation Association, Western Chapter of the International Society of Arboriculture, California Association of Pest Control Advisers, and water districts. In addition, we authored several new UC ANR publications: Sustainable Landscaping in California (publication 8504), Keeping Plants Alive under Drought or Water Restrictions (publication 8553) and Drought Tip: Use of Graywater in Urban Landscapes in California (publication 8536).

\section{Irrigation system malfunctions resulted in more water loss than could be saved by selecting drought-resistant landscape species.}

\section{Irrigation system malfunctioning}

In both UC studies, irrigation system malfunctions resulted in more water loss than could be saved by selecting drought-resistant landscape species (Hartin and McArthur 2007; Hartin et al. 2017; Reid et al. 2017). This underscores the importance of proper selection, installation and maintenance of irrigation equipment. Having a landscape contractor firm provide hands-on training to demonstrate these recommended irrigation management practices to site managers significantly reduced water loss following the training in both UC studies (Hartin and McArthur 2007; Hartin et al. 2017; Reid et al. 2017).

\section{Emergency drought legislation 2014}

Beginning in 2014 (during our ETAF study), Governor Brown declared a state of emergency and signed consecutive executive orders to conserve water during the drought and beyond. On April 1, 2015, he imposed statewide mandatory water reductions due to the continuing drought. Important elements impacting urban landscapes included a mandated 25\% statewide reduction in residential and commercial potable water use through Feb. 28, 2016 (based on usage in 2013); replacing 50 million square feet of turf with droughtresistant plants; prohibiting the use of potable water for irrigating turf on public street medians and on new landscapes not irrigated with drip systems; requiring urban water suppliers to enact pricing structures consistent with meeting statewide water restrictions; and requiring urban water suppliers to provide monthly information on water usage, conservation and enforcement permanently.

In addition, the 2015 order required CDWR to update MWELO to increase water efficiency in new and existing landscapes by using more efficient irrigation systems, gray water, and stormwater capture and by limiting turf. Using newer technologies such as precision irrigation hardware and software and renewable energy-powered desalination were also encouraged.

On April 7, 2017, Governor Brown lifted the drought emergency in all counties except four (Fresno, Kings, Tuolumne and Tulare, due to their reliance on groundwater) but maintained policies that support a core commitment to long-term water conservation through continued mandates on water use reporting, reducing water loss and decreasing the reliance on potable water for landscape irrigation.

\section{Decrease in urban water use}

While comprehensive results and impacts of public policy legislation aimed at increasing landscape water conservation have not been fully evaluated, recent data shows a decrease in urban water use. Total urban potable water use was $20 \%$ less in May 2017 than in May 2013 (an estimated savings of 124,537 acre-feet per month) (California Water Boards 2017). The U.S. Geological Survey reported a $17 \%$ reduction in urban water use throughout California between 2010 and 2015, driven in part by mandatory water restrictions in 2015 (Dieter and Maupin 2017). Perhaps more importantly, per-capita water use has fallen steadily over the past two decades, from 232 gallons per day in 1995 to 178 gallons per day in 2010, in response to long-term efforts at conservation, including reduced amounts of water applied to California landscapes (Mount and Hanak 2016). A blip occurred in 2015 when per-capita water use fell to only 130 gallons per day under mandatory conservation.

Input from many organizations and stakeholders impacted landscape water use policy and decreased water loss. While UC did provide policymakers with credible and objective research-based information, implementing MWELO and adjusting MAWA required a collaborative effort by a wide variety of groups and individuals vested in maintaining healthy, functional landscapes that perform acceptably under water reductions. 


\section{New landscape water use legislation}

In May 2018, Governor Brown signed two bills (SB 606 and $\mathrm{AB}$ 1668) consistent with his 2017 Making Water Conservation a California Way of Life proposal. SB 606 focuses on landscape water use and $\mathrm{AB} 1668$ focuses on rural and agricultural water use. Together they establish water use objectives and reporting standards for indoor and outdoor residential and commercial use; require SWRCB and CDWR to adopt long-term standards for efficient water use; update urban water management plans to include the reliability of the water supplies and strategies for meeting current and future water needs; require urban water suppliers to conduct a water supply and demand assessment and make water shortage contingency plans available to customers; and require water suppliers to declare emergency measures to ensure sufficient water for human consumption, sanitation and fire protection.

AB 2371 was enacted on Sept. 28, 2018. It continues to enforce many current landscape water conservation practices in and out of drought, including hydrozoning, water budgeting, stormwater collection, use of recycled water and irrigation equipment maintenance. In addition, it requires the Contractors State License Board to update the C-27 landscape contractors' exam as needed to include questions on new and emerging landscape irrigation efficiency practices; allows potential purchasers of housing units containing in-ground landscape irrigation systems to require irrigation system inspections; and requires the formation of a working group to examine and consider updating current consumer information on landscape water use. It also requires CDWR, following a public hearing every 3 years, to update MWELO or determine that an update is not needed and consider revising and updating the WUCOLS database.

\section{UC continues policy role, advances science}

UC continues to play a major role in providing objective information to policymakers as they formulate and update legislation on water conservation in commercial and residential landscapes. UC also continues to advance the science to conserve water and help ensure that legislative targets are met. Due to continued improvements in the efficiency of sprinkler and drip irrigation systems (which can decrease water loss), ETAF was further reduced in 2015 from 0.7 to 0.55 for residential landscapes (a reduction of $21 \%$ ) and from 0.7 to 0.45 for commercial landscapes (a reduction of $35 \%)$. Conservation on this scale will rely heavily on implementing best practices that decrease water loss, identifying new species of drought-resistant landscape plants and improving irrigation system performance. In practice, many irrigation systems fall far short of the irrigation efficiencies ( 0.81 for drip devices and
0.75 for overhead sprinkler devices) used in the current MWELO.

Bijoor et al. (2014) found that smart irrigation systems were more effective at reducing water loss than irrigation systems operated by conventional timers and that the difference exceeded water savings realized from selecting a warm-season (more water-conserving) turf species over a cool-season species. Reid and Oki (2016) continue to screen a wide variety of landscape plants for their drought resistance to expand the palette of California-friendly landscape plants. Work by their team has already led to the identification of hundreds of drought-resistant plants included in MWELO.
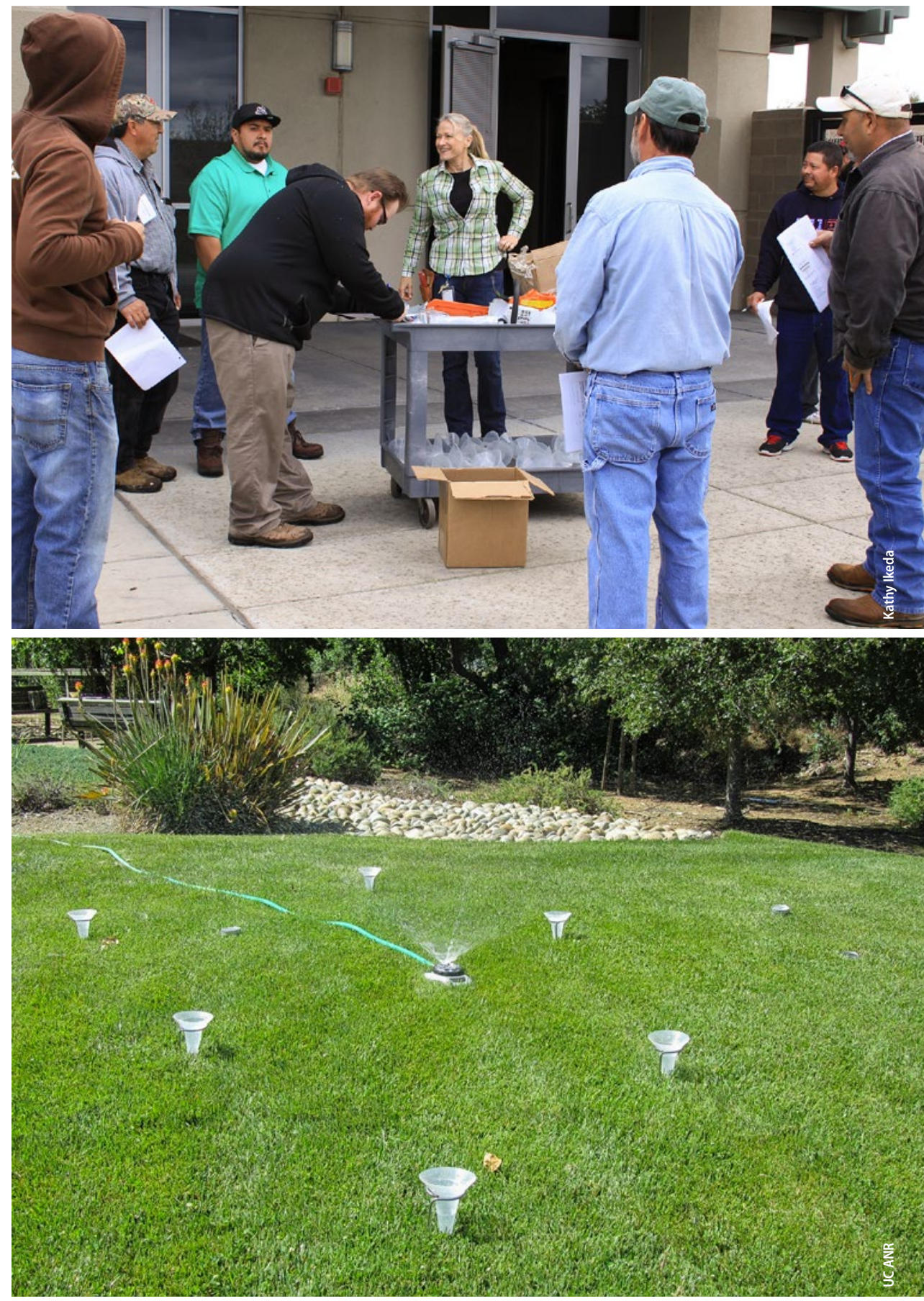
UC ANR Specialist Amir Haghverdi is leading a project to further define water requirements of turf under deficit irrigation and reclaimed water regimes; evaluate the performance of soil moisture-sensing and ET-based smart landscape irrigation technologies on water use effectiveness under deficit irrigation; and monitor turf responses to multiple levels of water stress using multispectral (measures reflectance over a wide range of wavelengths) and thermal remote-sensing techniques.

David Fujino and the Western Center for Agricultural Equipment established the SmartLandscape project at UC Davis in collaboration with more than 20 organizations and companies. SmartLandscape provides workshops and on-site training for landscapers and students on new water-saving technologies. Several UC faculty, specialists and advisors (Alison Berry, A. James Downer, Janet Hartin, Darren Haver, Karrie Reid and Igor Lacan) are involved in various projects throughout the state alone and in cooperation with the U.S. Forest Service and other groups to determine the long-term durability of a wide variety of underused landscape trees under warmer, drier conditions due to climate change (Hanak and Lund 2012) and urban heat islands. CA

J.S. Hartin is UC Cooperative Extension (UCCE) Area Environmental Horticulture Advisor in San Bernardino, Los Angeles and Riverside counties; L.R. Oki is UCCE Environmental Horticulture Specialist in the Department of Plant Sciences, UC Davis; D.W. Fujino is Director of the California Center for Urban Horticulture, UC Davis; K. Reid is UCCE Environmental Horticulture Advisor in San Joaquin County; C.A. Ingels was UCCE Horticulture Advisor in Sacramento County; D.L. Haver is County Director and UCCE Water Resources/ Water Quality Advisor, Orange County, and Director, South Coast Research and Extension Center, Irvine; and W.N. Baker is Principal, William Baker \& Associates, Temecula.

Authors received funding from California Department of Water Resources, Saratoga Horticultural Foundation, and Metropolitan Water District of Southern California.

Authors acknowledge the assistance and participation of numerous public and private landscape clientele and myriad partnering agencies and organizations over the course of these studies.

\section{References}

Bijoor NS, Pataki DE, Haver D, Famiglietti JS. 2014. A comparative study of the water budget of lawns under three management scenarios. Urban Ecosyst 17:1095-117. https://escholarship.org/Uc/ltem/16b5x8pz

California Water Boards. 2017. Fact Sheet: May 2017 Statewide Conservation Data. www.waterboards.ca.gov/water_issues/ programs/conservation_portal/ docs/2017jul/fs070517_may conservation.pdf

Costello LR, Jones KS. 2014. WUCOLS IV: Water Use Classification of Landscape Species. California Center for Urban Horticulture,

UC Davis. http://ucanr.edu/ sites/WUCOLS/

[CUWCC] California Urban Water Conservation Council. 2005. Water Smart Landscapes for California: AB 2717 Landscape Task Force Findings, Recommendations, and Actions. www. water.ca.gov/LegacyFiles/ wateruseefficiency/landscapeordinance/Model-WaterEfficient-Landscape-Ordinance/ Documents-Relied-Upon/ Water_\%20Smart_\%20Landscapes_\%20AB2717.pdf

Dieter CA, Maupin MA. 2017. Public supply and domestic water use in the United States, 2015. USGS Open-File Report 2017-1131. https://doi. org/10.3133/ofr20171131
Gibeault VA, Meyer JL, Youngner VB, Cockerham ST. 1985. Irrigation of turfgrass below replacement of evapotranspiration as a means of water conservation: Performance of commonly used turfgrasses. In: Proc 5th Inter Turfgrass Res Conf. Paris, France. p 347-56.

Haghverdi A, Wu L. 2018. Accounting for Salinity Leaching in the Application of Recycled Water for Landscape Irrigation. Southern California Salinity Coalition. www.socalsalinity. org/pdfs/SCSC-WACA-SalinityLeaching-White-PaperFeb-2018.pdf

Hanak E, Davis M. 2006. Lawns and Water Demand in California. Public Policy Institute of California, San Francisco. www. ppic.org/content/pubs/cep/ EP_706EHEP.pdf

Hanak E, Lund J. 2012. Adapting California's water management to climate change. Climatic Change 111(1):17-44. https:// doi.org/10.1007/s10584-0110241-3

Harivandi A, Baird J, Hartin J, et al. 2009. Managing Turfgrasses during Drought. UC ANR Pub 8395. Oakland, CA: UC ANR http://anrcatalog.ucanr.edu/ Details.aspx?itemNo=8395

Hartin JS, Fujino DW, Oki LR, et al. 2018. Water requirement of landscape plants studies conducted by the University of California researchers. HortTechnology 28(4):422-6.
Hartin J, McArthur K. 2007. Conserving Water and Improving Plant Health in Large Southern California Landscapes. Final Report. 2004 Proposition 50 Water Use Efficiency Grant. Grant No. 4600004211, CA Dept. of Water Resources (DWR) Office of Water Use Efficiency. Sacramento, CA.

Hartin JS, Meyer JL, Gibeault VA. 1993. Minimum Irrigation Requirements of Four Species of Landscape Trees. Research Report. UC ANR South Coast Field Station (now South Coast Research and Extension Center), Irvine, CA. $13 \mathrm{p}$

Hartin J, Oki L, Fujino D, et al. 2017. Evapotranspiration Adjustment Factor Study: Final Project Report. DWR Office of Water Use Efficiency, Sacramento, CA.

Kjelgren R, Rupp L, Kilgren D. 2000. Water conservation in urban landscapes. HortScience 35:1037-40.

McNitt AS, Petrunak DM, Serensits TJ. 2008. Temperature amelioration of synthetic turf surfaces through irrigation. Acta Hortic 783:573-81. https:// doi.org/10.17660/ActaHortic.2008.783.59

Mount J, Hanak E. 2016. Just the Facts: Water Use in California. Public Policy Institute of California, San Francisco, CA. www. ppic.org/publication/water-use in-california/
Nouri H, Glenn EP, Beecham S, et al. 2016. Comparing three approaches of evapotranspiration estimation in mixed urban vegetation: Field-based, remote sensing-based and observational-based methods. Remote Sens 8(6):492.

Oki LR, Reid K, Sisneroz J. 2016 Landscape plant irrigation trials. Acta Hortic 1140:145-50. doi:10.17660/ActaHor-

tic.2016.1140.31

Pittenger D, Downer AJ, Hodel D, Mochizuki M. 2009. Estimating water needs of landscape palms in Mediterranean climates. HortTechnology 19(4):70-4

Pittenger DR, Shaw DA Hodel DR, Holt DB. 2001. Responses of landscape groundcovers to minimum irrigation. J Environ Hortic 19(2):78-84.

Reid K, Fujino D, Oki L, et al. 2017. Maintaining urban landscape health and services on reduced irrigation: A multi-site study in best management practices. In: Proc ISHS 1st Int Sym Greener Cities for More Efficient Ecosystem Services in a Climate Changing World, Sept. 12-15, 2017. Bologna, Italy. Reid SK, Oki LR. 2008. Field trials identify more native plants suited to urban landscapes. Calif Agr 62(3):97-104. https://do org/10.3733/ca.v062n03p97 Reid K, Oki L. 2013. Irrigation and climate zone trials of perennial plants for sustainable landscapes. Acta Hortic 980:95-102. https://doi.org/10.17660/ActaHortic.2013.980.12
Reid K Oki LR 2016. Evaluation of ornamental plant performance on four deficit irrigation levels: Working with industry to promote sustainable plant choices for summer-dry regions. Acta Hortic 1112:155-62. https://doi.org/10.17660/ActaHortic.2016.1112.22

St. Hilaire R, Arnold M, Wilkerson DC, et al. 2008. Efficient water use in residential urban landscapes. HortScience 43:2081-92.

State of California. 2010. Model Water Efficient Landscape Ordinance. Department of Water Resources Office of Water Use Efficiency. www.water.ca.gov/ wateruseefficiency/docs/ MWELO09-10-09.pdf

Tanji K, Grattan S, Grieve C, et al. 2007. Salt Management Guide for Landscape Irrigation with Recycled Water in Coastal Southern California: A Comprehensive Literature Review. Southern California Salinity Coalition. 320 p. http://salinitymanagement. com/Literature_Review.pdf

Williams CF, Pulley GE. 2003. Synthetic surface heat studies. College of Agricultural, Consumer and Environmental Sciences, NMSU. http://cahe.nmsu. edu/programs/turf/documents/ brigham-young-study.pdf 